\title{
WestVirginiaUniversity
}

THE RESEARCH REPOSITORY @ WVU

West Virginia Agricultural and Forestry Experiment

Davis College of Agriculture, Natural Resources

Station Bulletins

And Design

$1-1-1957$

\section{Choose comfortable stalls for your dairy cows}

I. D. Porterfield

A. D. Longhouse

H. O. Henderson

Follow this and additional works at: https://researchrepository.wvu.edu/ wv_agricultural_and_forestry_experiment_station_bulletins

\section{Digital Commons Citation}

Porterfield, I. D.; Longhouse, A. D.; and Henderson, H. O., "Choose comfortable stalls for your dairy cows" (1957). West Virginia Agricultural and Forestry Experiment Station Bulletins. 410.

https://researchrepository.wvu.edu/wv_agricultural_and_forestry_experiment_station_bulletins/394 @ WVU. It has been accepted for inclusion in West Virginia Agricultural and Forestry Experiment Station Bulletins by an authorized administrator of

The Research Repository@WVU. For more information, please contact ian.harmon@mail.wvu.edu. 
Bulletin 410

lovember 1957

\section{OMFORTABLE STALLS}

\section{Con MEAN.-}

More Production

Less Injuries

Cleaner Cows

More lying down time for your cows

\section{COMFORTABLE STALLS For YOUR Dairy Cows}

\section{CLEANLINESS TRIALS}

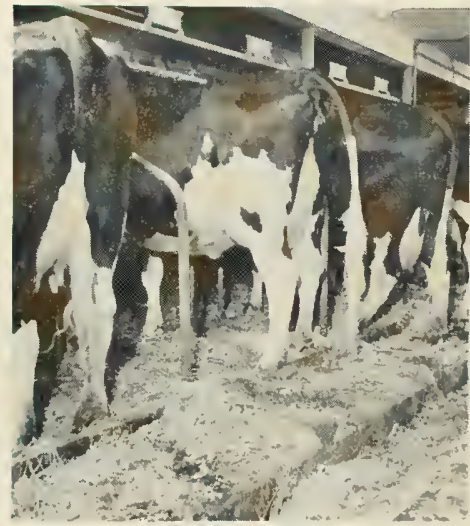

Cows in comfort stoll at the beginning of a seven-day cleonliness trial.

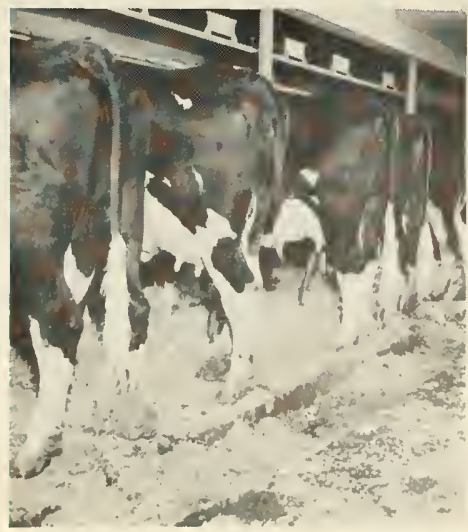

Cows in tie-chain stall of the beginning of a seven-doy cleanliness trial.

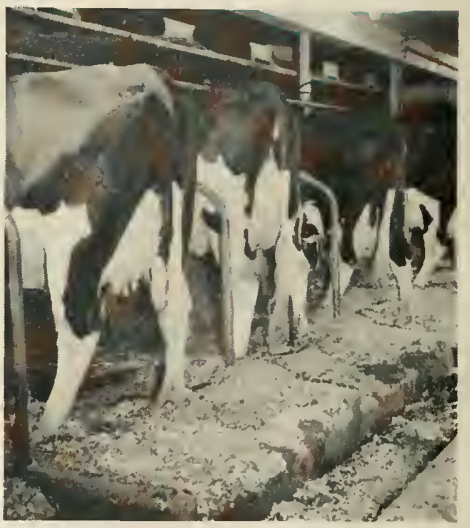

Cows in comfort stall at the end of a seven-day cleonliness triol.

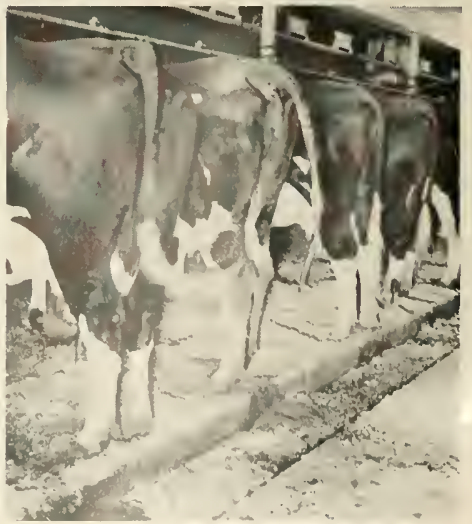

Cows in tie-chain stall of the end of a seven-day cleanliness trial. 


\section{THE AUTHORS}

luthors of Chouse Comfontable stalls for Four Daim Cones are 1. I). Porterfielel, prolessor and Head al Dairy Husbandry and Datiry Lusbandnan in the Igricultural Experinent Station: \. I). Longhouse, Prolessor and l Tead ol Igricultural linginecring and Igriculumal Engineer in the Agriculoural Experiuncut Station; and H. (). Henderson, Prolessor of Dain Husbander and Dain Husbandman in the Igricultural Experiment station.

\section{ACKNOWLEDGMENT}

The atuhor wish to expless their alppreciation to the Standard Bam Equipment Company, Bel Lir. Ilarvand, for their contributions (s) this projer. The Compint provided stanchions and modifred comfort stalls, and shared the expense of intallation.

\footnotetext{
Mest V'irgini. I Nilikshis

LGRICULTUR.M. HXPRTIMNT STITION

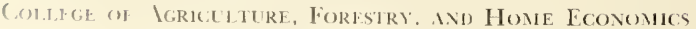

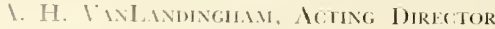

MORGANTOWN
} 


\section{Choose COMFORTABLE STALLS For YOUR Dairy Cows}

I. D. PORTERFIELD, A. O. LONGHOUSE, and H. O. heNDERSON

\section{Part I. A COMPARISON OF COMFORT AND TIE-CHAIN STALLS}

\section{Introduction}

D IIRI cows 111 nonthem l'nited states spenel more time in the birn than on pasture, and so the stall that witl give the most comlort to the cow and the most comvenience to the dairyman is of great importance.

Some dairymen stable one of the larger breceds of elairy cattle in stalls that were designed for a smatler breed. The breed change was matle without giving combideration to enlarging the stall. Other dairymen attempt to keep both large and small breeds in talls designed for the smatl brecels. For example, the stanchion stall was instalied when the barn at the llest Virginia [niversty Dairy fanm was built in I62I. This stall, which is 12 inches wirle and 66 inches long, was the recommended sice at that time. but it is now considered to be both too narrow and too short and is not comfortable for Holstein cows.

In such stalls the cow's real leet ane olten in the gutter, when lying town a portion of her udcler is in the gutter. Such cows are dity, and there are often many conclitions conclucive to mastitis. In addition, narrow stalls often result in bruised flanks and smash. ed teats.

\section{Comparison of Comfort and Tie-Chain Stalls}

The objective of this study wats to determine it the we we significant dillerences in milk poduction, deanliness, incidenees of mastitis, injuries, and in time spent lying fown between Holstein cons kept in comlort stalls and those kept in lie thain stalls. The differences in the anomme of bedding moed and in the time reguided for a latuning were also determined.

\section{Procedure}

Datat for this experiment were collected during the winter monthe lor eluree vears on the Holstein herel of the Whest Virginia Luiversity Igricultural Experiment Station. Cows in his herd wese alowe aterage in sife and hatce aresiged mote than 150 pounde of butterlat per year lor the last ten years.
The so-called comlort stall was at Hoarel-type statl. It was 81 inches long and ts inches wiele with a crossbar at the rear of the stall, adjustable to the sire of the cow, as shown in ligure I. When the cow was standing, she was forcel by the pipes in the front of the statl to stand with her rear legs back of the arsbar so that the droppings and urine were always back of the crossbar. When hing down, the cow's hear would go under the pipes enabling her to tic in Iromt of the crossbar.

The tie-thain stall was 66 inches long and 12 inches wide, as show in Figure?.

During the furst vear, two Holstein cows were placed in comfort stalls and production data were collented. Latter, upon the addition of six more comfort stalls, the llolstein herd was divited, and cight cors, representative of the various ages, wee placed in the comfort stalls and sercin in tic-chatu stalls. The following veat, the cont in comlont stalls the previons year were placed in the tie-chain statls and those that were in the tic-chain stalls were plated in combort stalts. This posechure of reversing the cows eath lall was folkowed throughour the experiment. Herd replacements, comsisting of lirst-atlf heifors, were cepuatly divided between the two types of stalls.

Throughout the experiment, all coms were led roughage simitar in guality and all that they would comsume. larele cow was giren at 15 percont crude potein gain misture fed accosding to the amount of milk produced, execpl that no cons received more than 16 pounds of grain per dial. IH conss were milked two times daily. Inaily milk weights were kept and when totaled were conected lor age by fatom used by the burean of Dairy budusto.

Derring the experiment 1.5 cows hatel one and in some cases two lactations in both the combers and ticelarin stalls that could be companed. These tecords were made when the coms were in the same stage of lattation.

lintore the cows were put an the experinemt,

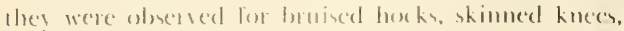
swollen knose an sides, and their tendenss to lice on the crossbiat of in the gutter. Ilecreatter, eath cow 


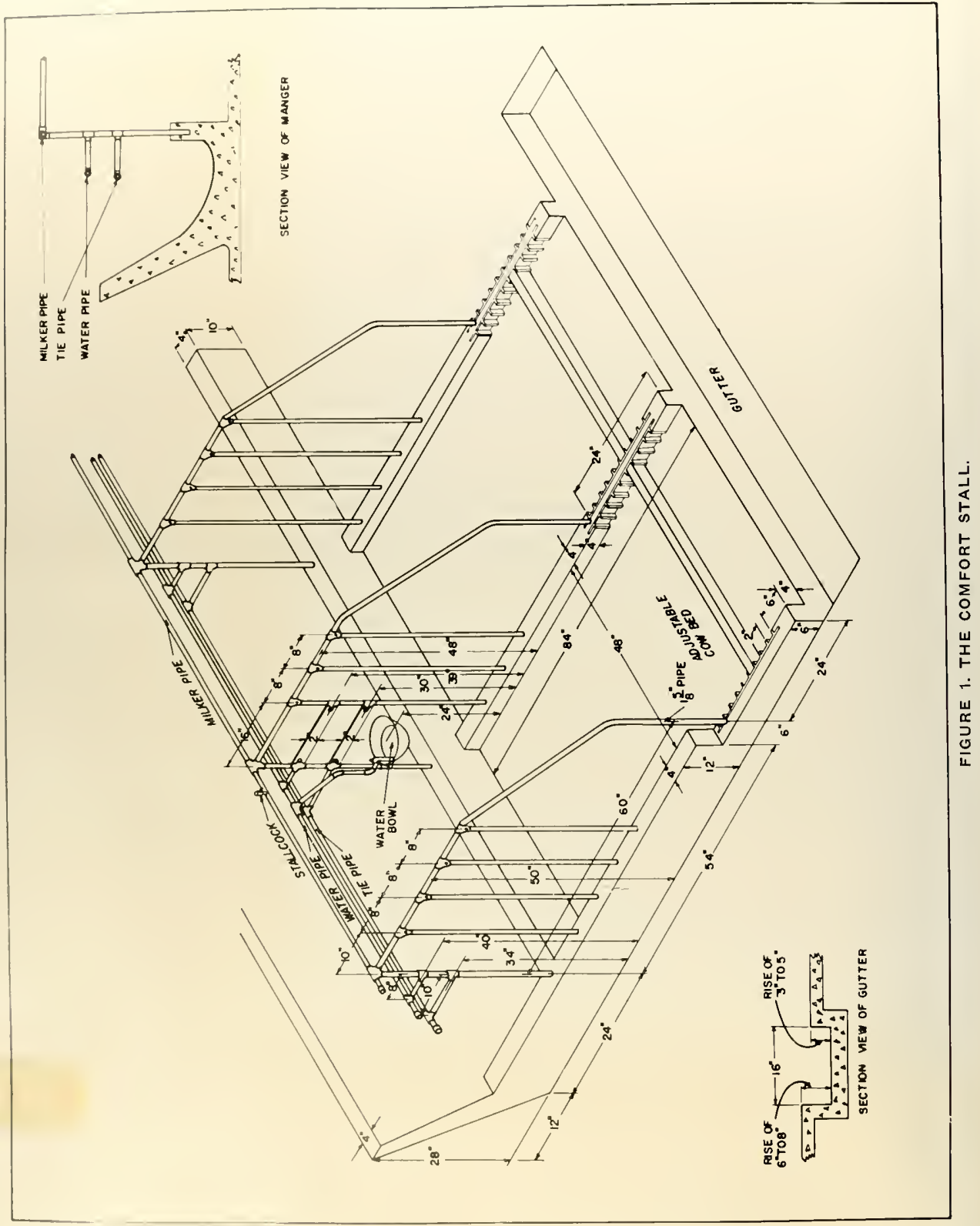




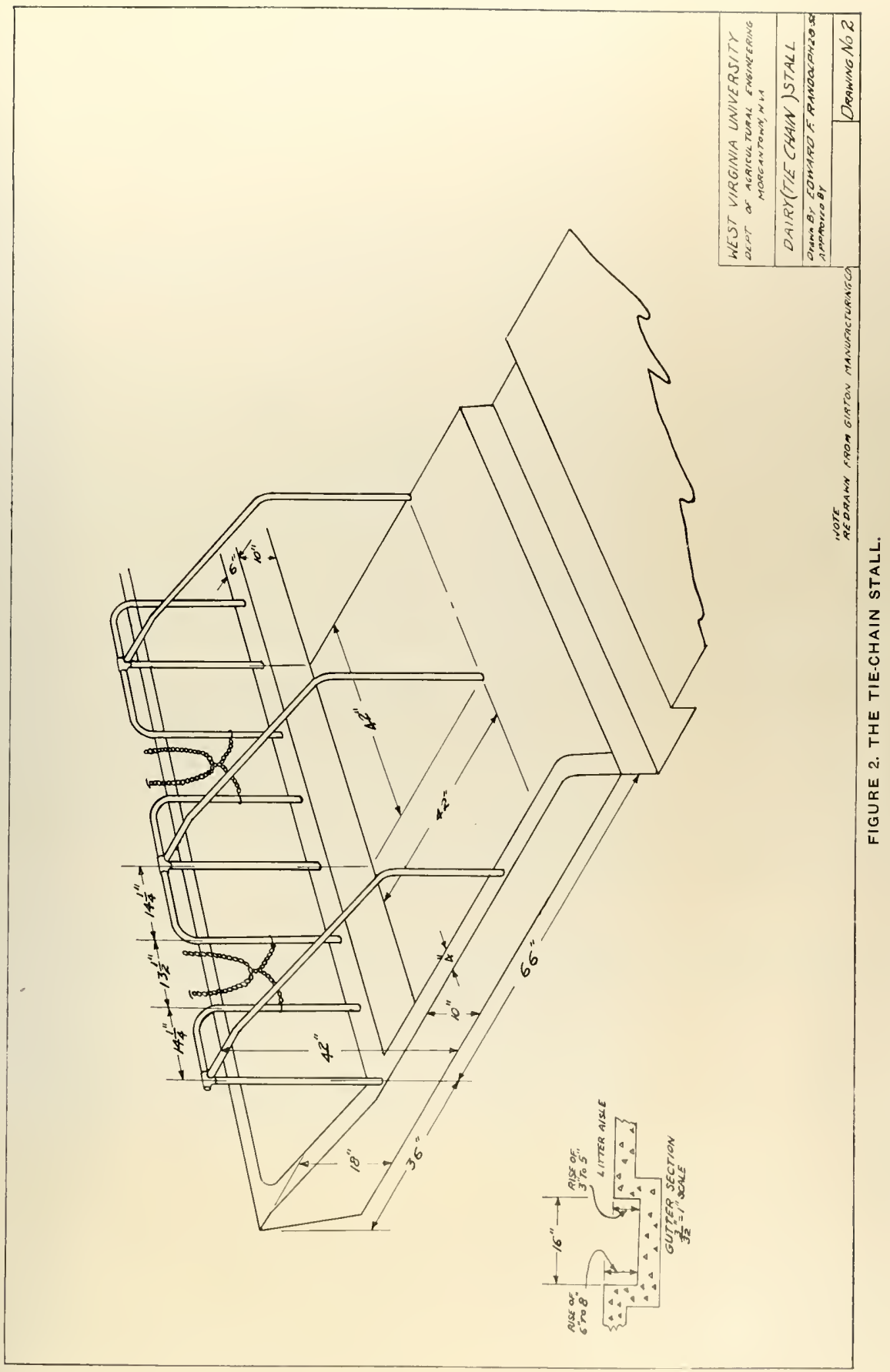


observed three time per weeh for injurix los which the stall might be comselered to be the antibuting fatuse.

Data were collected in the amomut of bedeling uscel in eath type of stall lor a heven-day period during one season and a filtecn-dat period doming a second season. Wood sharings were uscal for bedding. line and motion studies ware makle on the anomo of time necesary to clean the dilferent types of talls on nine different acasions.

Ihree, 7-1f-clay comparisoms on the cleanliness of the cows in the combort stalls with those in the tiedrain salk were made. It the leginning of each trial all visible manure was removed from the bodics, llanks, tails, and legs of each cow and then the cows were not brushed or curied again motil the trial had ended. During the trials the cows were scored daily on the following basis: ()-No visible sigms of manure or stain; 1-Stained but no manure: 2-Stained and/on mamme on hocks or tails: 3-Stained and/or manure on looks and tail; I-stained and/or manure on hocks, tail, and one llank; 5-stained and manure on hocks, tail, and both flanks.

A comparison of the anount ol time cows spent lying down in each type of stall was made by using themocouples and a recording potentioneter. Each time a cow got up or laid down the device recorded the number of the cow and the time to the nearest five minutes. Data were obtained over a period ol 19 days.

\section{Results}

\section{PRODUCTION}

The average weekly milk production (2x M.E.) for the 15 cows in the comparison is slown in Table I. Each cow had at leas one production record made in each type ol stall. Nine of the 15 cows produced

Table 1. I Comparisod of thr. Mrrage Wrehly

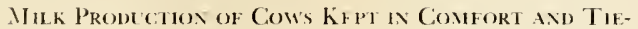
Chati SIAlls

\begin{tabular}{|c|c|c|c|c|}
\hline \multirow[b]{2}{*}{ Cow No. } & \multirow[b]{2}{*}{ WEEKA } & \multicolumn{2}{|c|}{ MiLK Prodvetion While IN } & \multirow{2}{*}{$\begin{array}{c}\text { DIFFEREXCE } \\
*\end{array}$} \\
\hline & & TIE STALL: & $\begin{array}{l}\text { COMFORT } \\
\text { STALLS }\end{array}$ & \\
\hline 1 & 17 & $\begin{array}{l}168 . \\
103\end{array}$ & $\begin{array}{l}176 s . \\
26.4\end{array}$ & $\begin{array}{l}\text { lbs. } \\
+71\end{array}$ \\
\hline $\begin{array}{l}1 \\
2\end{array}$ & 17 & 162 & $\begin{array}{l}21,4 \\
239\end{array}$ & $\begin{array}{l}+71 \\
+77\end{array}$ \\
\hline 3 & 23 & 183 & 281 & +98 \\
\hline 4 & 19 & 205 & 324 & +19 \\
\hline 5 & $1+$ & $14+$ & 459 & +15 \\
\hline b & 25 & $23 x$ & 296 & +58 \\
\hline 7 & 14 & $31 t i$ & 399 & +83 \\
\hline 8 & 16 & $\therefore+i 2$ & $37 t$ & +12 \\
\hline 9 & 16 & 4112 & 382 & -20 \\
\hline 10 & $3 n$ & 3601 & $3+5$ & -12 \\
\hline 11 & 15 & 118 & lit & 54 \\
\hline 12 & 9 & 191 & 225 & +34 \\
\hline 13 & 22 & 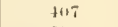 & 288 & -119 \\
\hline 14 & 13 & 213 & 161 & -52 \\
\hline 15 & 23 & 231 & 104 & -127 \\
\hline
\end{tabular}

indicates that the cow produced more milk while in the indiates that the cow produced more milk while in the

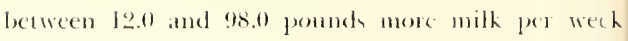
whike in comlent sall than while in the tie-chain stall. six cown produced between l2.0 to 127.0 pounds more milh por week while in the tic-ahain still than while in the comblom tall.

\section{INJURIES}

Doung the thre year ol this experiment $19 \mathrm{in}$. juries were sustitincel by aws in the amolort statl as compared to 11 by those in the tie-chain stall. Five llank injuries were sllstaind by the cows in the tiechain stalls and none by those in the combort stalls. All other injuries were either bruined hocks or skinneel knees.

\section{BEDDING}

For a seven-cha period the tie-chain stall requilcel an average of 16.6 poumde of bedeling (wood havings) per stall per (aty as compared with 16.9 pounds for the comfort stall. During a period of 11 days the tie-chain stall required an average ol 1.1 .1 pounds of beekling per stall per day compared with 16.2 pounds for the combort stall. The dillerence in the anount of beckling required lon the tic-chan and comlort stalls for the 14-day period was analyed by the analysis of valiance and found to be not signifi. (al)t.

\section{TIME REQUIRED FOR CLEANING STALLS}

Time and motion studies were made on the amomnt of time required to clean the tie-chain and combort stalls. The average time reguired to clean one tic-clsain stall was 28.64 seconds and to clean one comlont stall 35.12 seconds. This shows that the conlort stall required 6.48 seconds longer: however, this difference was mot statistically significant.

\section{CLEANLINESS}

The total sore for cleauliness in each trial is show'n in Table 2. In addition, belose and after pie. cures of cow's in each type ol stall for one seven-da! trial are shown on the cover. In each trial the cows in comlort stalls remained chaner than the coms in the tie-chain stalls. The first trial was conducted shortly after the cows were moved into their stalls from pasture and they had not become properly ad. justed to the stall: this probably accounts for the pororer cleanliness some during this trial.

\section{TIME SPENT LYING DOWN}

1)uring a lo-elay period, cows in the combort stalk spent an arerage of 10.2 hous per day lying down. whercas the cows in the tic-chain stalls spent an avesage ol 8.8 hours per day lying down. This dil ference was found to be highls significant. During a second trial, alter the com had exchanged stalls. the dillerence wan cren greater. The cows in the com lort stalls spent an average of 10.6 hours per das lying down as empared to 7.5 homs lor the eows in the tie-chain stalls. 


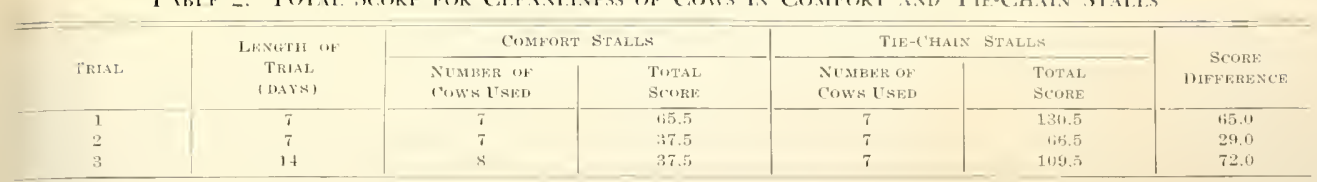

\section{Discussion}

Ihe lact that the cows in the combot stalls spent mone time lying down than clid those in the tie-chain stalls indicates that they were more comfortable. Ihis mat be one of the easoms why many of the corts in combort stalls produced more milk than they did when in tie-chain stalls.

The comfort stalls were wieler than the tie-chain stalls, which eliminated llank injuries caused by the pipe partitions of the stalls, and longer with a crossbar in the rear. which helped retain the bedding beneath the cows, thus keeping them cleaner. The combination of added length and more bedding beneath the front and rear legs largely prevented knce and hock injuries.

Fewer cows can be kept in a given space in com fort stalls that in tic-chain stalls since six comfort talls occupied the same space in width at diel seven diechain stalls. The comfort stall is 18 inches longer than the tie-chain. When two rows of comfort stalls are installed, the additional 18 inches requitcment for length per cow will require a stable ? leet wider than the conventional stable. This conlel mean that planmers of dairy stables may need to consider a change in designs.

Nost manulacturers of barn equipment sell more stanchion stalls than either the tie-thain or comfort statl. I coiticim of the experiment elescribed herewith wan that the comparisoms should have been made betreen the stanchion and the comfort statl, but in this stable the tie-chain stalls were being used for several years prior to the leginning of this experiment, and since the tienthain statl offers the cow more frectom of movement than does the stanchion, it would be expected that the diflerence in perfomance of cows would be even greater if stanchion stalls hat becn used. I question that remained unanswered is: Would there have been any difference in performance of the cows if the two types of stalls had been equal in plattorm witht and length?

\section{Summary}

1 comparison of Holstein cows kept in comfort and tie-chain stalls was mate. Based on 15 companioms, 9 cows produced trom 12 to 98 pomels more milk per week while in the comfort stalls.

Cow's kept in comfort stalls sustained fewer injuries, remained cleaner, and spent significantly more time lying down.

The dillerence in the amount of bedding used and cleaning time for each type of stall was not statistically significant.

\section{Part II. A Comparison of Comfort, Modified Comfort, and Stanchion Stalls}

\section{Introduction}

T

THE study reported in Part I has been criticised by clairy barn equipment manulacturers because it diel not include the stamehion statl. The reason for this criticism was that the stanchion stall repreented a lange portuon of stall rales. There was alos one unanswered question from the provious sudy: namely, would there have been any diflerence in the resules it the two types of stalls had bech equal in platlom wiclth and lemgth?

The ofjectises of this studs were to detomme if there are significant dillerences in milk protuc(ion, cleanfincss, injuries, time spent lying down, and anount of bedeling uned between Holstein cows hept in comfort, motified combort, and samehion stalls.

\section{Procedure}

Data for this experinent were collected during the winter months in five different years from the Holstein head of the West Virginia I'nisersity Igri(ultural Experiment Station.

The comfort stall wais the same as described in liat I of this study. I dhawing howing the deign and dunconsions are given in Figure 1 (to" wide andel $8.1 "$ long).

The modifical comfort stall, (ligure 3) resembles the comlort stall in elesign. Howerer, the plattom in

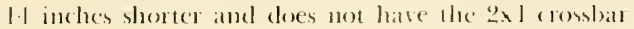
at the sean of the platform. In adelition, the three pipes alesos the front of the stall were moved forward If to 16 inches funther than those on the fromt of the 


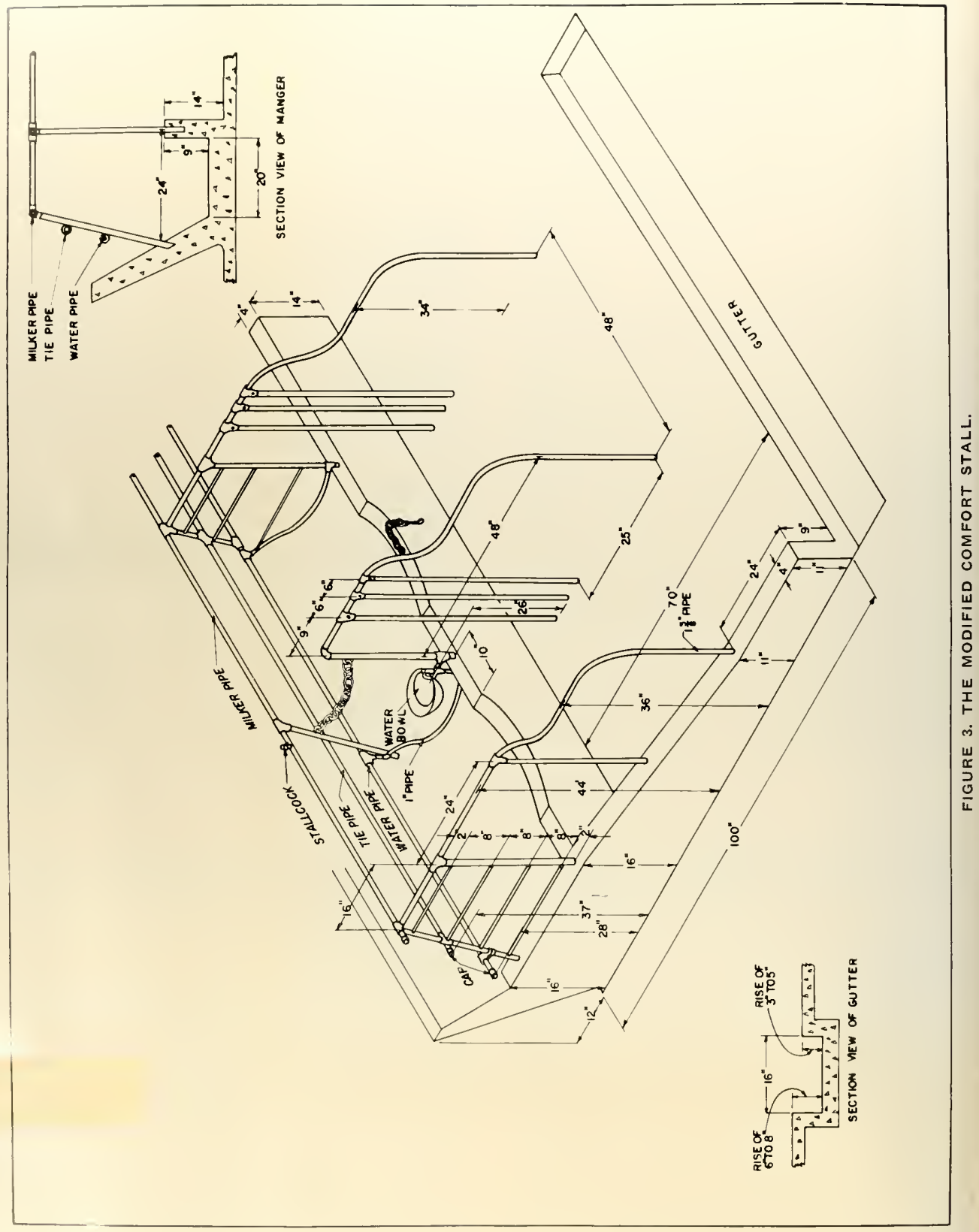




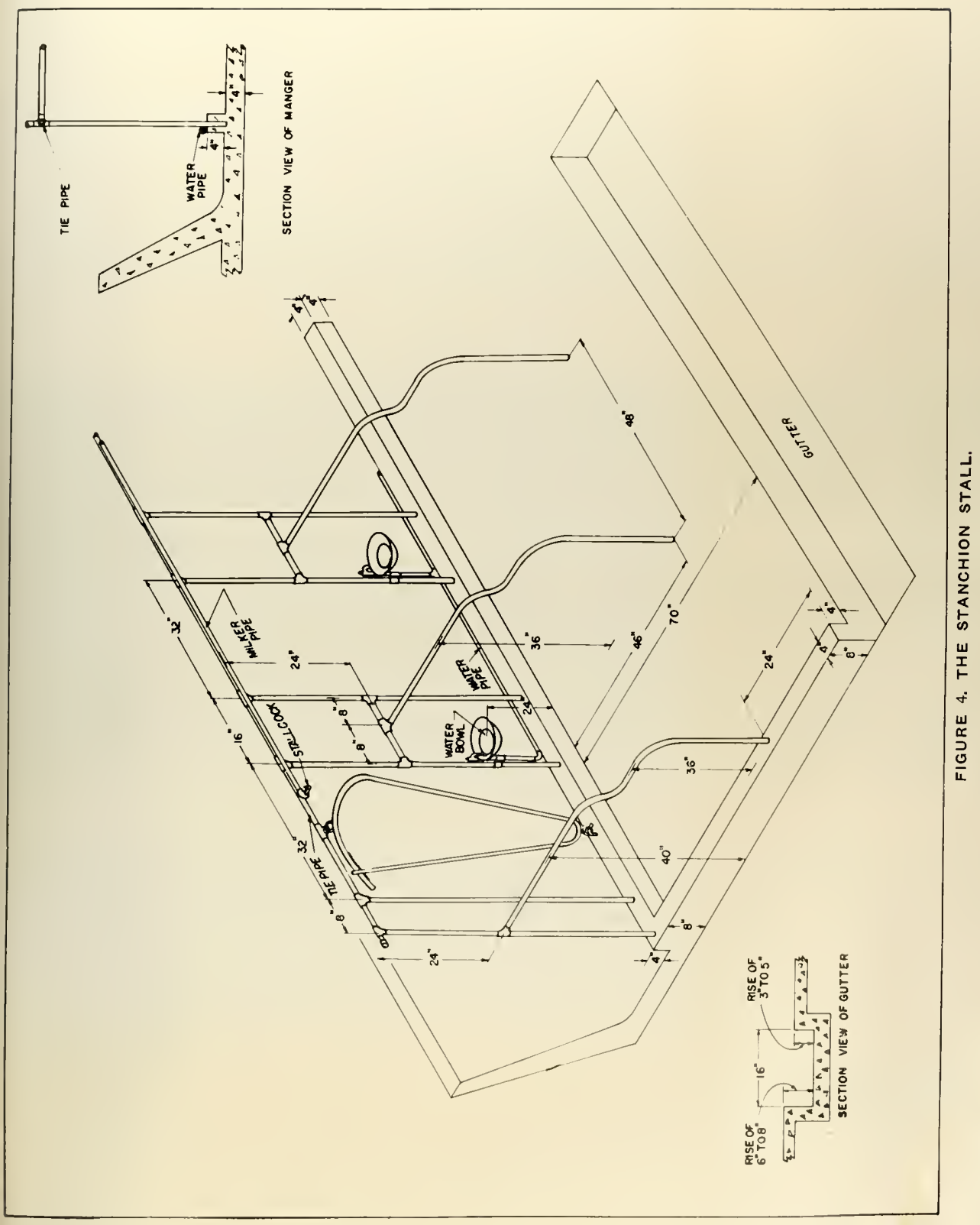




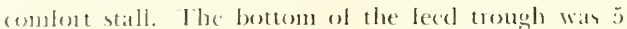
inches above the plathom lesel. The platlomm was Is incher in widh and 70 inches in length.

The stanchion stall (Figure d) Mats esscutialls the same clesign as those mamulactured for the last 25) vears. Ihe plathom in these experimuntal stalls was 18 inders wide and 70 indes lomg.

The Holstein herd was divided so that there were six coms in the comlont stalls, six in the modified comJont stalls, and fise in the stanchion stalls. Cow representative of varoms ages were placed in each type of stall and the gromps were kept as molorm at pos sible. The secomel year and each year thereader the cows were ansigned a different type of stall in order that their performance could be studied for these successive years, each year in a different tyje of stall.

feeding and mandgement of the cows in this study were similar to that described in the furs patt of this bulletin (page 3).

The procedure in this study was the same as that followed in Part I with the following exceptions:

(1) Restults of the cleanliness trials were determincel by taking plotographs at the beginning and encl of each trial. No attempt was male to score each animal, and (2) the amount of time spent lying down was determincel by an clectric eye and a recording potentimeter.

\section{Results}

\section{PRODUCTION}

The average weekly milk production (2x M.E.) lor 13 ans for which production records were obtained in all three types ol stalls is shown in Talsle 3. seven of the cows produced more milk while in the stanchion stall than while in the other stalls. Four poduced more milk while in the comfont stall and two produced more while in the modified combort tall. One com (No. 8) produced esscontially the same amome of milk while in both the comfort and stanchion stalls.

I ABLF 3. I COMPARISON OF THE AVERAgF WEEKIY IILK PROHETION OF COW' KIPT IN CMIFORT,

MUAFIFI) COMFOR' AND SIANCHON STAI.S

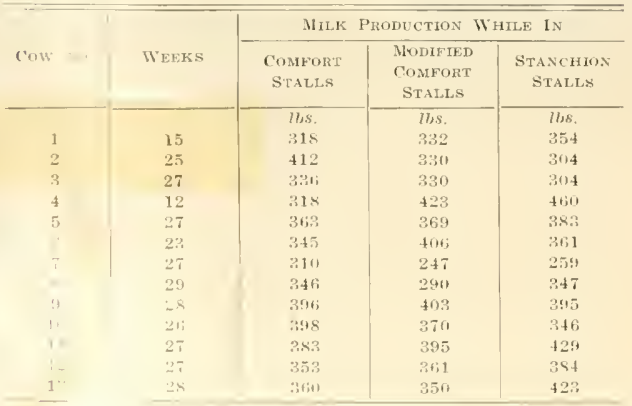

\section{INJURIES}

foring two bears of this study, I2 cows in com lore stalls sustaned th injurion, I's in modified com fort stalls stostaincel ge injuries, and 10 cows is stanchions smatancel gol injunies. All of the injurie. were cither skinned hocks or skinned kness excep lor one badly swollen hock which developed on on com in a ramchion stall. In addition, three forst-cal heilers persinted in lying on the cossbat of the com lort stall until the $2 \times 4$ crosshal was replaced with gati c rossloal.

\section{BEDDING}

The ansomt of beckling (wood shavings) reguire per stall per day was determined lor earle type o stall lor a period of the years. The comfort stat

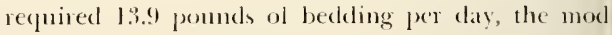
ficd comlort 11.0 pounds per day, and the standhio 14.0 pounds per dat.

\section{CLEANLINESS}

During this study two clcanliness trials were cos ducted. Photographs were taken before and alter on seven-day trial and are shown in Figures 5-10. In eac trial the cows in comlort stalls remained the cleat est: howerer, those in the modified comfort stall wer a close second. Those in stanchions were rated a por third in comparison to cows in the other stalls.

\section{TIME SPENT LYING DOWN}

Orer at thecyear period cows while in the con fort stalls spent an average of 10 hours 36 minut lying down per day. The same cows spent 9 hou: 20 minutes lying down in the modified comfort stal and 9 hours 30 minutes lying down in the stanchio stall.

\section{Discussion}

When Holstein corss were kept in stalls of equ size, whether comlort, modified comfort, or stanchios very little difference in cow performance was note This is particularly true in regard to production, i juries, and time spent lying down.

The modified comfort stall required almost thr pound, less bedding per day than the other III stalls.

Con's in comlont and modified comfort stalls 1 mained much eleaner than those kejt in standic stalls. I partial explanation for this may be th the cows in stamchion stalls were more restricted their movement.

In Pitse 1 of thin study it will be noted th the cows kept in the larger stalls out-milked tho kept in smaller stalls. This, coupled with the far obtained lrom Part II of this study, has led th atuthors to revise recommended cow stall dimension These scommendation are shown in Table 4 . T) type of stall that a dairyman selects would be a matt of individual prelerence; however, he should keep 


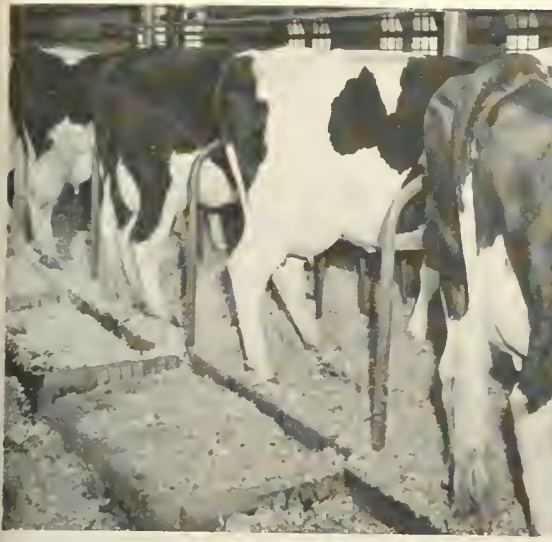

FIGURE 5. Cows in Comfort Stalls at beginning of one-week cieanliness trial.

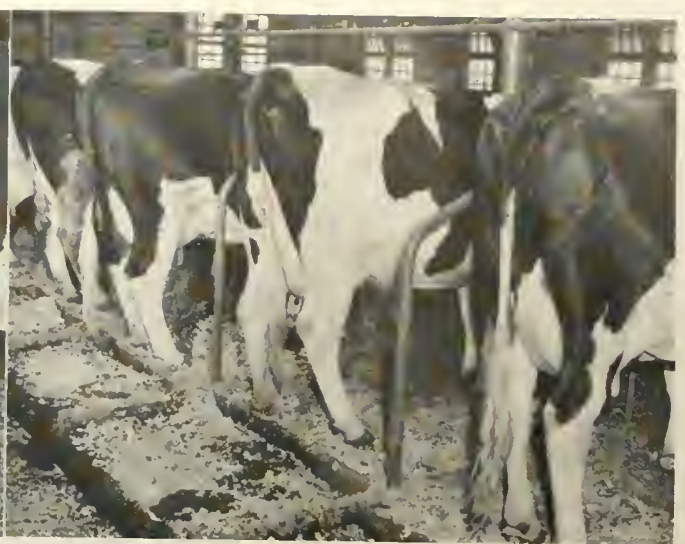

FIGURE 6. Cows in Comfort Stalls at

the end of a one-week cleanliness trial.

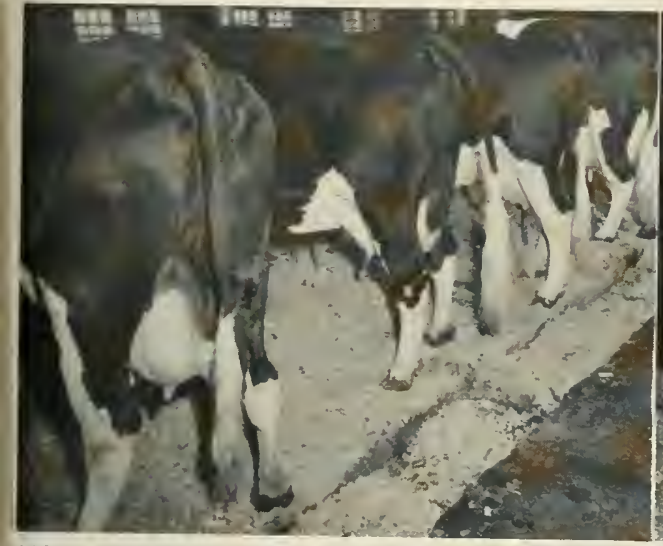

FIGURE 7. Cows in Modified Comfort Stalls at beginning of one-week cleanliness trial.

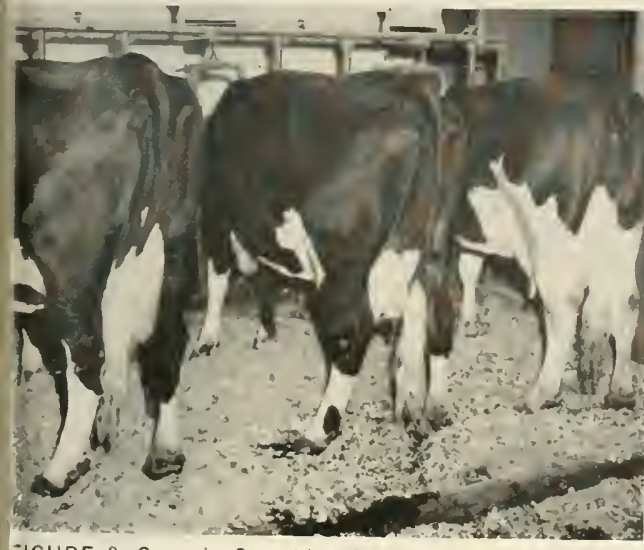

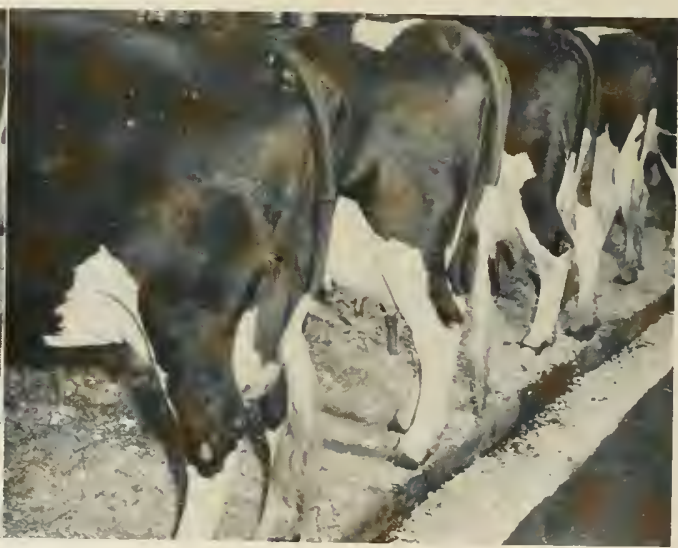

FIGURE 8. Cows in Modified Comfort Stalls at the end of a one-week cleanliness trial.

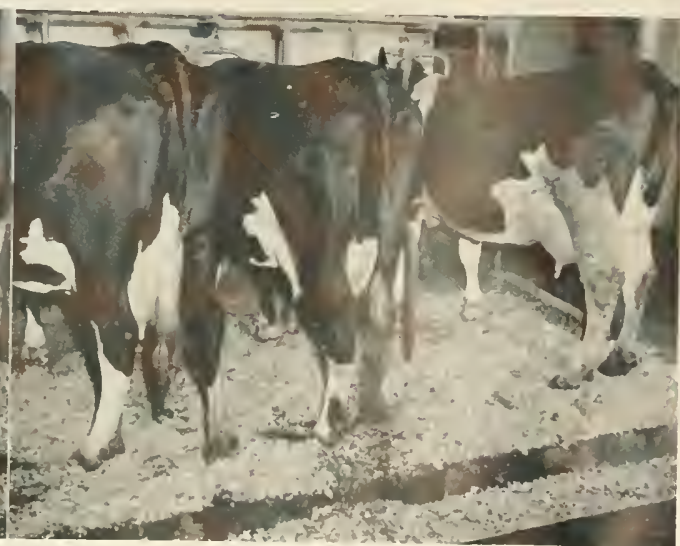

FIGURE 10. Cows in Stanchion Stalls at the end of a one-week cleanliness trial. 


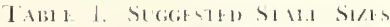

\begin{tabular}{|c|c|c|c|}
\hline \multirow[b]{2}{*}{ BEEED } & PLI: & (17.) L I , , & \multirow{2}{*}{$\begin{array}{l}\text { PlatFITH } \\
\text { WIITti }\end{array}$} \\
\hline & COMFUI & 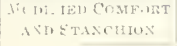 & \\
\hline $\begin{array}{l}\text { Ayr hre and Guernsey . } \\
\text { Holstein and Brown swiss } \\
\text { Jersey }\end{array}$ & $\begin{array}{r}111 . \\
i 4 \\
72\end{array}$ & $\begin{array}{l}\text { int } \\
\text { lit } \\
\text { i- } \\
\text { (ii) }\end{array}$ & $\begin{array}{l}12 \\
46-4 x \\
4 x-52 \\
43-41 ;\end{array}$ \\
\hline
\end{tabular}

mind whon compang pices that the water and vacsum lines ane included in th lowh the combort and modilect comlont stalls.

\section{Summary}

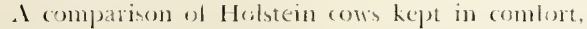
modified comfort, and stamelinon stalls ras made.

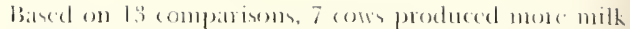
while in stanchiom atalls than whole in eithes of the wher types of walls. Fism producel mone milk whil. in comblort stalls and two produced mose milk while in molificel combort salls.

Ihere was essentially no difference betwech cows kept in the three types of stalls in regatrd to injuries and time spent lying down.

the combert sall requinced l:s.s pounds bedeling per day, modilied comfort 11.0 pounds, and the stanchion stall 1 l.0 pounds of hedeling per das.

Cows kept in the combort and modifical combont stalls remained cleaner than thone kept in standions. 